\title{
Notes
}

\section{Inventing a Nonexclusive Patent System}

\author{
John S. Leibovitz
}

Consider a slightly fictional scenario.' The year is 1879 . Two inventors, Edison and Swan, are both developing a pioneering technology-the incandescent lamp. Working independently on different continents (Swan in England, Edison in the United States), the two men labor tirelessly to find a combination of materials and manufacturing processes that will provide a reliable and cost-effective source of illumination for the modern age. After years of false starts and minor improvements, it appears that each is on the verge of a breakthrough. Swan recognizes the importance of using a slender, high-resistance lighting element, abandoning platinum in favor of carbon as his material of choice. He also sees the value of a vacuum-sealed bulb and has even found a way to treat the element so that it does not give off destabilizing gases and water vapor. Meanwhile, Edison progresses in a similar manner. He comes to appreciate the advantages of carbon and vacuum sealing. Toward the end of the year, Edison makes one more significant advance, which puts him a step ahead of Swan. After experimenting with many different kinds of materials, he realizes that carbonized vegetable fibers make for excellent, long-lasting filaments. Confident that he has discovered a workable solution to the problem, Edison obtains a patent. ${ }^{2}$

1. The following account is loosely based on the actual events of 1879 , but has been simplified and changed at points to emphasize the element of simultaneous invention. For a full account of the historical developments surrounding the invention of the light bulb, see ARTHUR A. BRIGHT, JR., THE ELECTRIC-LAMP INDUSTRY 35-69 (1949).

2. The real patent was U.S. Patent No. 223,898 (issued Jan. 27, 1880). See Figure 1, infra.

2251 
2252

The Yale Law Journal

[Vol. 111: 2251

FIGURE 1. EDISON's INCANDESCENT LAMP

T. A. EDISON.

Electric -Lamp.

No. 223,898.

Patented Jan. 27, 1880.

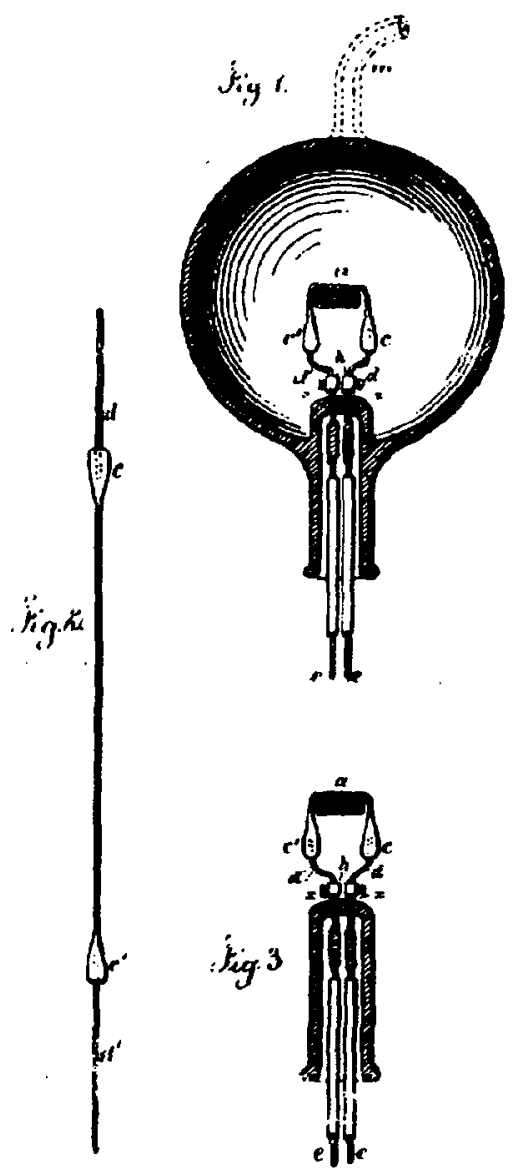

titinesses

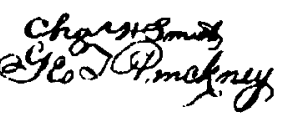

cyinevites.

Frances Il. Ellison

Hemedrefondes

arris.

Imaged with the Permission of Yale Law Journal 
The race is over and to the winner go the spoils. Later, Swan catches up to Edison, but his efforts mean little now, since Edison has exclusive rights to the first commercially viable light-bulb design. Over the next several years, Swan remains on the sidelines, prevented from capitalizing on his know-how lest he infringe Edison's patent. ${ }^{3}$ And Swan is not the only frustrated inventor-Edison does not hesitate to sue anyone who uses his technology. Moreover, Edison shrewdly leverages his initial monopoly into an even stronger position by patenting a continuous stream of smaller refinements and process improvements that competitors, lacking rights to the underlying technology, are slow to devise. Edison thus translates his development lead into a lasting competitive advantage, which he uses as he pleases to maintain high prices and block others from entering the market.

This simplified adaptation of a paradigmatic patent parable illustrates some widely acknowledged tensions in the patent system. On the plus side, the patent system provides a great incentive for Edison (and, for that matter, Swan) to invent a better electric lamp. In the absence of a patent system, Edison might try to protect his design by keeping it secret. Secrecy probably would not do him much good, however, since it would not be difficult for a competitor to reverse-engineer his light bulb once it hit the market. The patent allows Edison to avoid the risk that a competitor might use the fruits of his labor against him by copying his invention and introducing a competitive product while having borne little cost and even less risk. In technical terms, the patent allows Edison to appropriate the returns from his inventive efforts by granting him exclusive rights to make use of the invention for a limited period of time.

But Edison's patent comes at a price. Swan commits enough time, resources, and talent in his effort to invent the light bulb that he can run neck and neck with Edison, at least for a while. Yet ultimately, in the winner-take-all patent race, Swan is left with very little to show for his investment. This outcome is obviously undesirable from Swan's perspective. Swan may have been just months away from reaching Edison's milestone, but he is relegated to a second-tier competitive position once Edison's patent issues. Society also suffers. Edison's patent gives him the power to set prices and exclude competitors-not only Swan, but also new entrants-from the market. As a result, society is deprived of the benefits of healthy competition in the market for incandescent lighting and suffers for the duration of the patent (or longer, given Edison's ability to leverage his

3. As a matter of historical fact, Swan's company merged with Edison's in England in 1883, creating the Edison \& Swan United Electric Company, Ltd. The combined company was able to exert monopoly power in Great Britain - shutting down competitors and charging high pricesuntil Edison's patent expired in 1893. In the three years after the patent lapsed, fifty new brands emerged on the market, although this number dropped to thirty by the end of 1896 . BRIGHT, supra note 1 , at 107-09 
original patent to secure additional downstream patents). Edison is able to make more money by charging higher prices for fewer light bulbs, thereby maximizing his own private welfare at society's expense.

Controversy over granting exclusive rights to new technologies is as old as the patent system itself. As long as there have been patents, policymakers and academics have argued about the best way to balance the interests of inventors such as Edison, competitors such as Swan, and the general public. The debate has taken different forms over the years. In the nineteenth century, a vigorous anti-patent movement used a variety of economic and natural law arguments to question the value of patents. ${ }^{4} \mathrm{By}$ the end of the century, the patent advocates had won. ${ }^{5}$ While a number of economists continued to debate the pros and cons of patents, the basic existence of the patent system was never really in question. ${ }^{6}$ In the second half of the twentieth century, academic commentary increasingly looked for ways to fine-tune the patent monopoly by optimizing along two main dimensions of patent length and breadth. ${ }^{7}$ More recently, as high-tech industries have tested the flexibility and responsiveness of the patent system, the debate has begun to turn in a new direction. Several writers have proposed new systems for specialized industrial circumstances, many of which merge aspects of various intellectual property regimes. ${ }^{8}$

In this Note, I pose a simple question: What would happen if society gave both Edison and Swan the right to commercialize the light bulb? My hypothesis is that the exclusivity assumption of patents represents another dimension, alongside the familiar dimensions of breadth and length, that policymakers can manipulate to improve the efficient production and dissemination of new technologies in society. The question may sound paradoxical to some - after all, isn't exclusivity the defining attribute of a

4. See Fritz Machlup \& Edith Penrose, The Patent Controversy in the Nineteenth Century, 10 J. ECON, HisT. 1 (1950).

5. Id. at 6.

6. See Fritz Machlup, Subcomm. on Patents, Trademarks, and Copyrights of the Senate Comm. ON THE Judiciary, 85Th Cong., An Economic Review of the Patent SYSTEM 25-44 (Comm. Print 1958).

7. Compare Richard Gilbert \& Carl Shapiro, Optimal Patent Length and Breadth, 21 RAND J. ECON. 106 (1990) (suggesting that optimal patent length may be infinite if breadth can be adjusted accordingly), with Nancy T. Gallini, Patent Policy and Costly Imitation, 23 RAND J. ECON. 52 (1992) (making the opposite claim that optimal policy consists of broad patents with a lifespan adjusted to achieve the desired reward). Several empirical studies have shown, however, that inventors prefer trade secrecy to patent protection in many circumstances. See WESLEY M. COHEN ET AL., PROTECTING THEIR INTELleCtUAL ASSETS: APPROPRIABILITY CONDITIONS AND Why U.S. MANUfaCtuRING FIRMS PATENT (OR NOT) 25. 28 (Nat'l Bureau of Econ. Research, Working Paper No. 7552, 2000); Richard C. Levin et al., Appropriating the Returns from Industrial Research and Development, 1987 BROOKINGS PAPERS ON ECON. ACTIVITY 783, 79398.

8. See, e.g., J.H. Reichman, Legal Hybrids Between the Patent and Copyright Paradigms, 94 Colum. L. REV. 2432 (1994); Pamela Samuelson et al., A Manifesto Concerning the Legal Protection of Computer Programs, 94 COLUM. L. REV. 2308 (1994); Lester C. Thurow, Needed: A New System of Intellectual Property Rights, HARV. BuS. REV., Sept.-Oct. 1997, at 95. 
patent? It may even seem anti-American. ${ }^{9}$ Nevertheless, I show that the idea falls well within the bounds of theoretical viability. In framing the hypothesis, I align myself with a small number of economists who have begun to evaluate the benefits to be gained by lifting the patent exclusivity constraint, ${ }^{10}$ an idea that thus far has scarcely infiltrated the legal academy. ${ }^{11}$ By following an analytical approach that is less formalistic than those of the economic writers (but using similar basic assumptions), I hope to extend the conversation about nonexclusive patents to include lawyers and other policymakers engaged in the continuing debate about how to optimize the system to maximize social welfare.

My argument proceeds in five Parts. Part I provides a quick overview of the conventional wisdom behind the existing patent system. Part II identifies structural problems inherent in an exclusive regime. Part III makes a theoretical case for nonexclusive patents in comparison to other approaches to correcting the structural deficiencies of patents. Part IV offers an account of how nonexclusive patents could be implemented through minimal modification of the current patent laws. Part $V$ applies the theory of nonexclusive patents to some contemporary policy disputes as a means of demonstrating its applicability throughout the innovation lifecycle. Finally, I conclude with some thoughts about how the idea might be tested in practice.

\section{THE STANDARD ECONOMIC CASE}

My argument is best understood against the backdrop of what I call the "standard economic case" for patents. I frame the argument in economic

9. The Constitution empowers-but does not obligate-Congress to "promote the Progress of Science and useful Arts, by securing for limited Times to Authors and Inventors the exclusive Right to their respective Writings and Discoveries." U.S. CONST. art. I, $\S 8$, cl. 8.

10. Foreshadowing my argument, I should at this point raise the defense of independent invention and mention that despite an extensive and systematic search effort, I did not encounter the one published article proposing nonexclusive patents until after I had completed an initial draft of this Note. See Manfredi La Manna et al., The Case for Permissive Patents, 33 EuR. ECON. REV. 1427 (1989). A forthcoming article by Stephen Maurer and Suzanne Scotchmer continues this line of analysis and reaches some of the same conclusions as I. See Stephen M. Maurer \& Suzanne Scotchmer, The Independent-Invention Defense in Intellectual Property, 69 ECONOMICA (forthcoming 2002) (manuscript on file with author). Both of thest au iicles piesenit formal economic models of nonexclusive patent regimes.

11. Perhaps because of its mathematical, rather than institutional, emphasis, as well as its publication in a European economics journal, La Manna et al, supra note 10, has remained relatively unknown to American legal commentators. Only three law review articles have cited this article since its publication. Of these, only one treats the fundamental economics of patents. See Ian Ayres \& Paul Klemperer, Limiting Patentees' Market Power Without Reducing Innovation Incentives: The Perverse Benefits of Uncertainty and Non-Injunctive Remedies, 97 MICH. L. REV. 985, 1003 n.44 (1999). Ayres and Klemperer's proposal for a duopoly patent auction appears to be the closest idea in the legal literature to a fully nonexclusive patent system such as the one I propose. See id. at 1031-32. 
terms since economics is the dominant discourse for patent policy debates. Of course, patent theory is a highly diversified field. Although I touch on some differences between leading schools of thought, my discussion emphasizes common themes rather than differences among various theories. My aim in this Part is not to provide a comprehensive survey of the patent literature, but rather to establish a relatively noncontroversial account of the current system that serves as a theoretical backdrop for the nonexclusivity argument that follows.

Invention can be broadly understood as a production process whose output is applied knowledge (technical specifications, production processes, and the like) rather than physical goods. Unlike wheat, gasoline, or other material commodities, knowledge is an information good that can generally be copied at nearly zero marginal cost. Absent any special legal protection or government intervention, knowledge can be freely disseminated across a population of interested consumers. (This is increasingly true given the progression of information technology in recent decades.) Unconstrained technical knowledge thus fits the textbook definition of a public good: a commodity "for which the cost of extending the service to an additional person is zero and which it is impossible to exclude individuals from enjoying." ${ }^{12}$ For that reason, society faces not only special challenges but also special opportunities in maximizing its efficient production. The patent system, at its core, involves a bargain whereby inventors gain temporary exclusivity over their inventions in exchange for public disclosure of technical details. The standard economic case explains this bargain as a way of maximizing social welfare by providing incentives for inventors to increase the stock of applied technical knowledge in society (through protection) and discouraging inefficient redundancy of inventive effort (through disclosure).

\section{A. Protection: Providing Incentives To Invent}

The protection function generally receives the most attention in the patent literature. In a classic article, Kenneth Arrow outlines several problems that can inhibit optimal allocation of resources toward invention. ${ }^{13}$ First is the problem of inappropriability. The full value of some piece of unprotected technical information cannot be realized by its original possessor. Once it hits the market, copies may quickly appear, and the marginal price for others to acquire the information tends toward the marginal unit cost of zero. This effect creates disincentives to invest in

12. Paul A. Samuelson \& William D. Nordhaus, Economics 37 (17th ed. 2001).

13. See KENNETH J. ARROW, Economic Welfare and the Allocation of Resources for Invention, in 5 COLLECTED PAPERS OF KENNETH J. ARROW: PRODUCTION AND CAPITAL 104 (1985). 
technical improvements that are exposed to the public. As noted above, Edison would be reluctant to invest so heavily to find the best light-bulb design if he knew that competitors could sell knock-offs simply by imitating his final product.

If inappropriability presents supply-side impediments to invention, a second problem, indivisibility, interferes with the demand side. According to Arrow, " $[\mathrm{T}]$ here is a fundamental paradox in the determination of demand for information; its value for the purchaser is not known until he has the information, but then he has in effect acquired it without cost." 14 Suppose Edison develops the light bulb in his laboratory but needs to sell a stake in his invention to raise capital necessary to bring it to market. $\mathrm{He}$ might be suspicious of showing his invention to potential investors or licensees lest he give up his exclusive secrets. This suspicion, however, could very well turn off people who want to see the technology before they buy a piece of the action. In other words, it is impossible for Edison to provide a free sample of information without giving away the store. ${ }^{15}$

By giving inventors exclusive rights to useful, novel, and nonobvious technologies, the patent system solves the appropriability problem. ${ }^{16}$ Inventors can develop and sell knowledge without the risk that they will be unable to appropriate returns from their investment. Protection provides a greater incentive to develop new technology than would be the case without the patent system, although leading scholars disagree about what conceptual model best describes the incentive structure. ${ }^{17}$ Moreover, since a would-be user of the technology must obtain a license from the patent holder, the indivisibility problem disappears. Public disclosure of the invention allows potential licensees to see what a technology has to offer before paying for it, thereby facilitating a market in technical knowledge that otherwise would not exist.

\section{B. Disclosure: Channeling Investment Toward Novel Inventions}

In addition to providing incentives to increase the stock of technical knowledge through protection, the patent system serves a channeling function that encourages inventors to search for new technologies rather

14. Id. at 111.

15. Arrow identifies uncertainty as a third trait. He notes that it is very difficult to estimate the value of information, especially when it is brought to market as an input into the production of some other good. Id. at 110-11. Uncertainty afflicts the market for innovation regardless of the extent of protection afforded by a patent system, so I primarily focus on the first two characteristics in this Note.

16. See generally 35 U.S.C. $\$ \$ 101-103$ (1994) (listing conditions for patentability); id. $\$ 271$ (defining infringement); id. $\$ 281$ (providing a remedy for infringement); id. $\$ 283$ (authorizing injunctions to prevent violations of patents).

17. See A. Samuel Oddi, Un-Unified Theories of Patents-The Not-Quite Holy Grail, 71 NOTRE DAME L. REV. 267 (1996) (reviewing the main theories). 
than recreate old ones. The very same fact that poses incentive challenges with information goods-zero marginal cost of duplication-also presents cost-saving opportunities that do not apply to other kinds of markets. Unlike a material commodity, which requires additional expenditure for each incremental unit of production, information costs very little to reproduce ad infinitum once it has been developed. It is possible to distribute the knowledge to all who might need it, thereby allowing them to avoid the cost of producing it on their own.

The publication requirement ${ }^{18}$ capitalizes on this opportunity, allowing inventors to stand on the shoulders of their predecessors. Once inventors gain patent protection for their inventions, they have nothing to fear if it is disseminated widely, since anyone who uses the invention must get their permission first. Publication brings subsequent inventors up to the state of the art, so they can incrementally improve technologies others have already developed. By reviewing Edison's patent disclosure, Swan might abandon his duplicative effort and focus on improving Edison's technology. The aggregate cost of invention thus decreases, in theory, since inventive efforts are channeled away from redundant projects. This opportunity to eliminate redundant production efforts might be cost-prohibitive in the market for physical goods because someone would have to bear the costs of creating additional units of production for the entire population of potential users. As noted above, however, there is little incremental unit cost associated with dissemination of technical knowledge.

\section{PROBLEMS WITH PATENTS}

Patents do not come without costs. Swan's frustration in the light-bulb race illustrates how patents create winners and losers. This competitive dynamic poses obvious challenges to inventors. It can also affect social welfare. The question I address in this Part is whether the patent system, in solving the appropriability problem, goes too far in the other direction. Is there such a thing as too much appropriability? This is another well-trodden area of the patent literature. As in Part I, my goal is not to provide an exhaustive analysis, but rather to examine some of the inefficiencies raised by exclusive patent rights. In general, there are two varieties of problems: inefficiencies leading up to the invention of a technology and inefficiencies in the commercialization of technologies once they are invented.

18. 35 U.S.C. § 122(b) (Supp. V 1999). 


\section{A. Invention Inefficiencies}

The economically rational Edisons of the world constantly scan the development horizon for innovations that may augment their income streams. ${ }^{19}$ They weigh the likely benefits of an invention against the costs of development. They compare the cost of developing the invention in house with the cost of licensing from someone else who may be able to develop the technology more efficiently. In the end, if they decide to "build" rather than "buy," the patent system provides strong carrot-andstick incentives to develop new technologies as quickly as possible. The problem, from a social resource standpoint, is that speed is not always the most economically prudent course when it comes to technology development.

First, the carrot: Patents promise supernormal rents to the first inventor. Lack of competition following the issuance of a patent can give an inventor too much pricing power. In the case where the patented technology has no substitutes or substitution is cost-prohibitive, the patent leads to a market monopoly and the surplus profits that come from higher prices and reduced output levels. ${ }^{20}$ The case of total monopoly is rare because few technologies have no substitutes. Additionally, other conditions can limit a patentee's market power. For example, owners of complementary technologies may have sufficient bargaining power to negotiate the patent holder's prices downward, assuming it is in their interest to do so. The patent holder, however, does not need a complete monopoly to earn supernormal rents. The baseline for comparison is the "normal" profit the patent holder would earn in the absence of exclusivity. (Assume, for the time being, that competitive appropriation through reverse engineering is not a problem, so that "subnormal" profits are not an issue. I return to this point in Part III.) The patent holder must simply receive profits in excess of this baseline level. As long as the increase in profit from obtaining exclusive rights outweighs the increased costs associated with obtaining the patent (e.g., accelerated development schedules, or transaction costs of getting the patent itself), the patent provides a carrot for speedy development. The possibility of attaining exclusive control of a technology, beyond mere reverse engineering protection, provides a strong profit motive for expedited development.

Now, the stick: Inventors not only stand to reap supernormal gains if they are first to develop a technology; they also face the scary prospect that

19. This line of argument and the ones that follow assume that inventors are economically rational rent-seekers-not an uncontroversial point. My assumption, however, is that while the economic model may not apply to certain individual cases, it does apply on the larger scale, particularly in the modern industrial context.

20. See SAMUELSON \& NORDHAUS, supra note 12 , at 172 
someone else will beat them to the punch. A competitor that gains exclusive control over a desirable technology may prevent others from using the technology altogether. Alternatively, the competitor may exact some kind of payment in cash or in kind. The actual financial impact of the patent on the losers of the race depends on many factors, including the relative bargaining position of the losers versus the winners and the availability of substitute technologies. One can assume, however, that if the loser has actually committed to developing a technology, he believes that the benefits of owning that technology are greater than the benefits of obtaining it from a third party. Thus, the prospect of someone else getting a patent on a technology already under development is a strong incentive to finish first. In fact, this defensive incentive may be a more common reason to accelerate development efforts than the upside incentive, because the defensive strategy does not require the inventor to pay the significant costs associated with obtaining and enforcing a patent. The inventor simply needs to incorporate his innovation in a publicly marketed product or publish the discovery so that priority can be established over would-be patentees. ${ }^{21}$

At this point, the reader may be wondering why I am making such a big deal about accelerated technological development. Isn't faster better when it comes to innovation? Indeed, the common assumption is that faster is better. ${ }^{22}$ If there were no costs associated with increasing the pace of invention, the assumption would be well-founded. Accelerating technological development, however, does impose additional costs. One example is the incremental labor costs associated with solving a particular problem. To accelerate a research program may require increased staffing levels. Yet the marginal benefit of additional personnel may not keep up with the marginal cost of paying them.

To take a simple example, suppose Edison and Swan each employ two lab assistants to help with the invention process. Suppose they pay each assistant $\$ 50$ per month (not such a bad rate in 1879) to work on their projects. Imagine that Edison is six months away from putting the final touches on the incandescent lamp. In the six months before Edison completes the project (and Swan gives up in light of Edison's patent issuing), the two inventors each spend $\$ 600$ on lab assistants (2 lab assistants $\times \$ 50$ per assistant per month $\times 6$ months), for a combined labor cost of $\$ 1200$. Now consider an alternative case. Suppose Swan realizes that Edison is ahead. Swan decides to speed up his development schedule so he can finish the invention in five months (thus beating Edison with one month to spare). Unfortunately, given the progress of his project, more lab

21. See 35 U.S.C. $\S 102$ (a)-(b) (1994) (describing conditions that can lead to loss of patentability).

22. But see Yoram Barzel, Optimal Timing of Innovations, 50 REV. ECON. \& STAT. 348 (1968) (attacking this assumption). 
assistants do not translate linearly into greater productivity. Swan realizes that in order to complete the invention in five months, he will need to double his workforce to finish the job. Swan's labor expenditure increases to $\$ 1000$ over the five-month period (4 assistants $\times \$ 50$ per month $\times 5$ months), while Edison spends $\$ 500$ ( 2 assistants $\times \$ 50$ per month $\times 5$ months). Thus, the aggregate labor expenditure preceding the completion of the invention becomes $\$ 1500$. So Swan's decision to expedite the development schedule by one month costs an additional $\$ 300$ ( $\$ 1500$ over five months $-\$ 1200$ over six months).

Is this money well spent? That depends on whom you ask. Swan might think so because he might recoup his additional investment many times over by earning monopoly (or near-monopoly) profits and by avoiding payment of licensing fees to Edison down the road. From society's standpoint, whether the extra $\$ 300$ was well spent is an empirical question whose answer depends on any number of factors, such as the value society places on having the incandescent lamp one month earlier and the time it takes to go from the lab to the assembly line. (The longer the time lag, the more the value of the extra month decreases in proportion to the cost, because, all other things being equal, future light bulbs are worth less today than present light bulbs.) Note that while I chose the example of labor costs to make this point, I just as easily could have pointed to other costs, such as technology expenditures. ${ }^{23}$ It is important to remember that the inventors' private costs matter from a social standpoint because they represent opportunity costs. The extra $\$ 300$ spent on speeding up development of the light bulb by one month is $\$ 300$ that could have been spent on some other project, say, the phonograph. The investment in inventing the phonograph might, at the margin, yield more social benefit than an extra month of incandescent lighting.

Under normal circumstances, i.e., without the promise of supernormal gains from exclusivity or the peril of subnormal gains due to misappropriation by copiers, rational inventors will speed up or slow down invention in order to maximize return on their investment. This calculation necessarily incorporates the value society places on having the technology in question sooner rather than later, expressed through consumers' willingness to pay higher or lower prices, as well as the potential opportunity costs of the invention effort. To the extent that exclusivity increases the rents that a patentee stands to receive from an invention at the

23. In fact, technology inputs to invention may be a bigger constraint on accelerating development than other inputs such as labor, since new technologies often derive from existing technologies. Edison might have been able to shorten the time to develop his light bulb to a matter of days if he had possessed a supercomputer capable of running light-bulb simulations. But the cost required to invent the supercomputer would have been entirely prohibitive given the state of the art in 1879. See ARROW, supra note 13, at 113 (explaining that information is both a product and an input of inventive activity). 
expense of competitors and society, it distorts the normal operation of the price mechanism in the invention market. Exclusivity thus raises the possibility-stronger when there are fewer substitutes-of inefficient allocation of resources to invention.

\section{B. Commercialization Inefficiencies}

Much criticism of the patent system relates to inefficiencies that arise after a patent has been granted. Looking beyond the incentive structure that promotes invention, this line of reasoning focuses on the question of whether the patent laws impede the commercialization of protected inventions. The basic complaint is that even accounting for the wide range of patent doctrines that serve to narrow patent scope-for example, the doctrine of misuse and the reverse doctrine of equivalents ${ }^{24}$ - granting exclusive rights inherently encourages monopolistic behavior by patent holders. Patent holders may restrict output and maintain high prices, resulting in a deadweight loss to society where the aggregate loss of consumer satisfaction outweighs the monopolist's gain. ${ }^{25}$ As in other monopoly situations, patent holders might not face competitive pressure to exploit their property in as many innovative ways as possible. This subject has been hotly debated in the academic literature. I will briefly review two arguments against the monopoly viewpoint as a prelude to suggesting that the truth lies somewhere between the monopoly and antimonopoly accounts. The impediment to efficient commercialization probably does exist, but it is most noticeable in markets with special characteristics.

Perhaps the most direct criticism of the deadweight loss viewpoint is that it falsely equates exclusivity in the patent domain with the (undesirable) textbook case of monopoly from Economics 101. This argument has two parts. First, critics point out, it is a mistake to assume that a patented technology is a marketable commodity and therefore that exclusive control over the technology directly translates into monopoly power in some product market. ${ }^{26}$ Many patents, in fact, pertain to manufacturing processes or design features that cannot be marketed except as part of a larger portfolio of technologies packaged together. These other

24. 3 Peter D. Rosenberg, Patent Law Fundamentals $\$ 16.02$ [2], at 16-55 to -62 (2d ed. 2001) (misuse); id. $\$ 17.07[3]$, at 17-162 to -166 (reverse doctrine of equivalents). But cf. Tate Access Floors, Inc. v. Interface Architectural Res., Inc., 279 F.3d 1357, 1368 (Fed. Cir. 2002) (noting that the Federal Circuit has never found noninfringement based on the reverse doctrine of equivalents).

25. See SAMUELSON \& NORdhauS, supra note 12, at 197 (defining deadweight loss); see also Ayres \& Klemperer, supra note 11, at 987 (arguing that legal scholars have failed to appreciate the importance of deadweight loss in patent policy).

26. See Edmund W. Kitch, Elementary and Persistent Errors in the Economic Analysis of Intellectual Property, 53 VAND. L. REV. 1727, 1738-40 (2000). 
technologies might be patented by other inventors, thus encouraging reasonable cross-licensing of "exclusive" technologies. ${ }^{27}$ Second, even when a patent gives its owner the ability to control the production of a marketable good, the availability of substitutes often severely limits the patent holder's ability to extract monopoly rents. Inventors can sometimes "invent around" narrow patent claims or opt for an alternate technology that does not enjoy patent protection. Edmund Kitch has noted that patented technologies face competition from superseded technologies in the marketplace at the beginning of the patent's term, from close substitute technologies through the entire term, and from imitators as the patent is about to expire. ${ }^{28}$ As a result, patent holders may face pricing pressure throughout the term of their patents even though they have exclusive rights to a specific design or process. Competition between very narrowly differentiated patented technologies thus resembles monopolistic competition more than it does a full-fledged monopoly. ${ }^{29}$

Another important line of reasoning focuses on the strategic context in which technological competition takes place. According to this view, industry participants closely monitor and anticipate their competitors' developments. Faced with the prospect that a competitor might patent some essential technology, a firm has a number of options available to preserve its ability to maneuver. If it has a comparable research program underway, it may seek to publish interim results in a public journal, thus raising the bar for nonobvious invention and making it harder for a rival to exclude by obtaining a patent. ${ }^{30}$ Alternatively, a firm may seek a blocking patent on a complementary technology, thus giving it a defensive bargaining chip against patentees who could otherwise shut it out of the market. ${ }^{31}$ Often, offsetting blocking patents lead to broad cross-licensing agreements or patent pooling among industry leaders, allowing firms with offsetting patent portfolios to compete freely with one another.

While these and other theories easily dispel the simple view that patents unambiguously impede efficient commercialization of new technologies, it would be equally imprudent to conclude that the problem is altogether nonexistent. In fact, as Robert Merges and Richard Nelson have shown, history is full of instances in which the pace of commercialization has

27. As I discuss at the end of this Section, however, cross-licensing can sometimes lead to an oligopoly situation.

28. See Edmund W. Kitch, Patents: Monopolies or Property Rights?, 8 RES. L. \& EcON. 31 (1986).

29. Monopolistic competition is a situation where competing products are differentiated but nonetheless highly substitutable. A textbook example is the retail gasoline market. See SAMUELSON \& NORDHAUS, supra note 12, at 168-69.

30. Gideon Parchomovsky, Publish or Perish, 98 MICH. L. REv. 926, 927 (2000).

31. See Robert P. Merges \& Richard R. Nelson, On the Complex Economics of Patent Scope, 90 COLUM. L. REV. 839, 860 (1990). 
slowed following the successful enforcement of patents. ${ }^{32}$ For example, before 1891, the nascent incandescent lamp industry was characterized by rapidly intensifying competition and steadily decreasing prices. In that year, however, the Edison General Electric Company (the real one, not the fictionalized version described in the beginning of this Note) won an infringement case against a competitor based on Edison's seminal patent. ${ }^{33}$ Edison was able to obtain a series of injunctions that shut down a number of competitors, growing its market share from forty to seventy-five percent virtually overnight. Not only did the trend of decreasing light bulb prices end, but improvements in basic filament design almost completely stopped until the patent expired. ${ }^{34}$ Patent enforcement and complex patent litigation also may have slowed the development of such important technologies as the airplane, the radio, and possibly even the automobile. ${ }^{35}$

These facts suggest some theoretical limitations to the patent apologist's arguments. Kitch's substitution argument, for instance, appears to assume a linear, stepwise progression in technological development. In many cases, it is true that technologies advance by small steps, with competitors vying for incremental patent rights the whole way. As long as this is the case, substitutes may abound, since no invention will be radically different from those that precede it or compete with it. However, there are many instances where technological breakthroughs ("pioneer inventions") pave the way for a whole new class of technologies that either solve problems in much better ways than did previously existing technologies or solve problems no one has been able to solve before. ${ }^{36}$ Edison's light bulb is a good example. More modern examples might include breakthrough drug therapies or synthetic compounds. In these cases, control over an important patent could have a significant effect on the commercialization and further development of a groundbreaking technology, depending on the patent holder's larger business objectives, capabilities, and legal resources. ${ }^{37}$ Inventing around an important patent may be very costly, if not impossible.

In the case of the strategic gaming arguments, remedies such as patent pooling and cross-licensing may simply replace a greater evil (monopoly) with a lesser one (oligopoly). Competition in these markets is possible only for those companies whose existing patent portfolios give them a ticket to

32. See id. at 884-909.

33. Edison Elec. Lighting Co. v. U.S. Elec. Lighting Co., 47 F. 454 (C.C.S.D.N.Y. 1891), aff'd, 52 F. 300 (2d Cir. 1892).

34. Merges \& Nelson, supra note 31 , at $885-86$; see also BRIGHT, supra note 1 , at $87-91$ (describing the history in more detail).

35. Merges \& Nelson, supra note 31 , at 889-93.

36. John R. Thomas, The Question Concerning Patent Law and Pioneer Inventions, 10 HIGH TECH. L.J. 35, 45-64 (1995) (describing and criticizing the pioneer invention doctrine).

37. John H. Barton, Patents and Antitrust: A Rethinking in Light of Patent Breadth and Sequential Innovation, 65 ANTITRUST L.J. 449, 451-55 (1997). 
play the game or who are able to buy their way inside by paying licensing fees. These requirements may pose significant barriers to entry for newcomers. Since startup firms often chase technological opportunities that larger incumbents are unwilling or unable to pursue, the net result could be to impede innovation in many markets.

\section{Summing Up the Problem}

At this point, I want to take a step back from the details of the patent monopoly debate and offer two middle-ground statements about patents that I hope should be relatively uncontroversial. First, patent exclusivity raises the very real possibility of inefficient behavior by inventors in both the invention and the commercialization stages of technology development. Second, patent inefficiency is situationally complex. It depends on a wide range of factors, including the nature of the technology, the industry structure, the competitive position of the inventor, the size of the inventor's patent portfolio, and so forth. In short, the "patent problem" can be reduced to a simple formulation: Patents occasionally cause inefficient behavior, but it is a complex task to predict, a priori, exactly when these inefficiencies will occur.

\section{NONEXCLUSIVE PROTECTION: A THEORETICAL SOLUTION?}

If patent exclusivity sometimes leads to inefficient behavior, there are a number of possible remedies. The challenge is to find a solution that fits both parts of the problem as described above. The solution should alleviate monopolistic power while accommodating the practical peculiarities of different situations. In this Part, I rule out two plausible approaches before offering my hypothesis that a system of nonexclusive patents would provide the best theoretical solution.

\section{A. Ex Post Solutions}

One approach is to wait for problems to emerge and prosecute offending parties after the fact under the antitrust laws (or allow private parties to invoke the misuse doctrine as a defense to infringement suits). In other words, give Edison the rights to the incandescent lamp, but send the Feds after his company when it leverages its initial patent to gain monopoly power and squelch competition in subsequent years (even after the original patent has expired). 
Although this ex post approach has been out of vogue for many years, ${ }^{38}$ the FTC and the DOJ have recently held public hearings to reconsider the relationship between antitrust and patent law. ${ }^{39}$ The bar for antitrust-style remedies is high because the patent monopoly is presumed to lead to the creation of technologies and markets that otherwise would not exist. Historically, the government has needed to show price-fixing arrangements with nonpatentee competitor ${ }^{40}$ or tie-in licenses by which a patent is used to control the market for an unpatented good or extend the monopoly after the patent expires. ${ }^{41}$ The recent Xerox decision by the Federal Circuit Court of Appeals raised the bar even higher. ${ }^{42}$ The decision narrowed antitrust limits on the patentee's right to instances of illegal tying, fraud in the Patent Office, or sham litigation. ${ }^{43}$ The court noted that "a patent alone does not demonstrate market power" 44 and that "absent exceptional circumstances, a patent may confer the right to exclude competition altogether in more than one antitrust market." 45 In other words, antitrust actions cannot remedy economic inefficiencies that are intrinsic to the exclusive nature of patent rights absent some other market-distorting behavior.

Moreover, the antitrust process may be administratively ill-equipped to correct market abuses in today's fast moving, intellectual-property-based industries. As Richard Posner points out, these cases typically involve very complex determinations of fact that test the technical expertise of enforcement agencies and courts. The legal determination of monopoly may also be very difficult in rapidly changing industries. Combined, the factual and legal complexity can delay the implementation of remedies until well after the offending act. ${ }^{46}$ Former FTC Chairman Robert Pitofsky, while defending the antitrust authorities' ability to do the job, essentially agrees, lamenting that the process is "bound to be slow. All the government can hope to do is reduce delay to the maximum extent possible without short-

38. Id. at 449; cf. Mark A. Lemley, The Economic Irrationality of the Patent Misuse Doctrine, 78 CAL. L. REV. 1599 (1990) (arguing that the misuse doctrine should be eliminated and antitrust enforcement efforts stepped up).

39. See Competition and Intellectual Property Law and Policy in the Knowledge-Based Economy, 66 Fed. Reg. 58,146 (Nov. 20, 2001).

40. See, e.g., Standard Oil Co. v. United States, 283 U.S. 163, 175 (1931); In re Yarn Processing Patent Validity Litig., 541 F.2d 1127, 1137 (5th Cir. 1976).

41. 3 ROSENBERG, supra note $24, \S 16.02[2]$, at $16-57$ (misuse); id. $\$ 16.05[2]$, at $16-101$ (antitrust laws).

42. In re Indep. Serv. Orgs. Antitrust Litig., 203 F.3d 1322 (Fed. Cir. 2000).

43. Id. at 1327; see also Robert Pitofsky, Challenges of the New Economy: Issues at the Intersection of Antitrust and Intellectual Property, 68 ANTITRUST L.J. 913, 919-23 (2001) (assessing the importance of the ruling for antitrust law).

44. In re Indep. Serv. Orgs. Antitrust Litig., 203 F.3d at 1325.

45. Id. at 1327 . (2001).

46. Richard A. Posner, Antitrust in the New Economy, 68 ANTITRUST L.J. 925, 936-43 
changing consumers or undermining the rights of respondents." ${ }^{47}$ The result is that antitrust-style remedies may be ineffectual at curbing patent-related monopoly excesses and may even stifle capital investment in affected markets. ${ }^{48}$ Given these doctrinal and administrative challenges, it would be preferable to address the root cause of patent-related market abuses in the patent system itself rather than on a case-by-case basis after the damage has already been done.

\section{B. Tailored Liability Regimes}

Another way to solve the "patent problem" would be to isolate the conditions under which inefficiencies can emerge and craft liability rules that address specific problems that arise in preidentified contexts. J.R. Reichman has found precedent for this approach in the large number of hybrid exceptions to the dominant patent-copyright paradigms that have emerged internationally in response to specific industrial needs. Two examples are the International Convention for the Protection of New Varieties of Plants and registered design protection laws. ${ }^{49}$ Reichman and others have outlined proposals for new systems of rules that would impose automatic licensing requirements, predefined schedules of "differential user fees," and other liability rules fine-tuned to promote efficient invention and commercialization of technologies in different markets. ${ }^{50}$ Under such a tailored liability approach, the government might compel Edison to license his patent to Swan and other industrialists at a rate that reflects policymakers' best understanding of the economics of the nascent lightbulb industry.

The tailored liability approach, however, suffers from three inherent drawbacks. First, there is the empirical challenge of constructing situationspecific rules. Extensive empirical analysis is required to determine situations, e.g., industries, or preferably, generalized characteristics of industries, where patent inefficiencies exist. Second, complex liability rules must be enacted and implemented for various situations. Automatic licensing provisions will have to be negotiated. Specialized enforcement procedures will require administrative changes and possibly even specialized courts. Industry participants will have to pay for legal guidance through the reguiatory maze. All things considered, the cost and complexity of the system could be very high. Finally, technological change will test the

47. Robert Pitofsky, Antitrust and Intellectual Property: Unresolved Issues at the Heart of the New Economy, 16 BERKELEY TECH. L.J. 535, 557 (2001).

48. Posner, supra note 46, at 939.

49. Reichman, supra note 8 , at 2453-76.

50. Id. at 2544-55; see also Samuelson et al., supra note 8, at 2413-20 (proposing a hybrid regime tailored to the computer software industry). 
ability of rulemakers to update the system on a continuous basis. Fee schedules will need to be amended continuously and new rules added frequently to accommodate unforeseen developments.

While tailored liability rules may provide a viable option, especially when implemented on a case-by-case basis at the instigation of industry participants, they involve a brute-force legal approach. One wonders if a more elegant and generic solution could be applied across many contexts to respond dynamically to patent inefficiencies as they arise.

\section{Nonexclusive Patents}

The idea I propose in this Section in some ways resembles a hybrid of the patent, trade secret, and copyright systems. The basic concept is simple. I propose a patent system that, instead of granting exclusive property rights to the first inventor of a new technology, protects him against free-riding competitors, but not against competitors who independently develop the same technology..$^{51}$ In Part IV, I sketch a general outline of how this approach might work in practice. For the remainder of this Section, I assume that such a system is indeed practical in order to explain why, in theory, nonexclusive patents steer a safe course between the Scylla of misappropriation and the Charybdis of monopolistic power.

Even if the law must protect inventors so they can appropriate returns from their inventions, this does not necessarily imply that only the first inventor should be able to appropriate those returns. If Edison and Swan both come up with the light bulb independently but Edison happens to finish a month ahead of Swan, it may be wasteful to exclude Swan from commercializing his knowledge, assuming he did not pilfer the idea from Edison. If, instead of producing knowledge, the two inventors produced some nonpatentable tangible commodity-say wheat-one would expect head-to-head competition.

The problem in the technology context is that it might be very easy for one inventor to compete by using the knowledge developed by another. This situation would be analogous to farmer Swan stealing farmer Edison's surplus wheat and competing against him by selling the stolen goods on the open market. Such a situation would obviously provide a big disincentive

51. Another way to imagine this proposal is as a trade secret regime with a right against reverse engineering. Trade secrets typically protect relationships and not inventions themselves. See RESTATEMENT (SECOND) OF TORTS $\$ 757$ (1982); RESTATEMENT (THIRD) OF UNFAIR COMPETITION \& 40 (1995); UNIF. TRADE SECRETS ACT \& 1(2)(ii), 14 U.L.A. 433, 438 (1990); Gale R. Peterson, Trade Secrets in an Information Age, 32 Hous. L. REV. 385, $391-409$ (1995); see also David D. Friedman et al., Some Economics of Trade Secret Law, J. ECON. PERSP., Winter 1991, at 61 (analyzing the economics of trade secrecy); Pamela Samuelson \& Suzanne Scotchmer, The Law and Economics of Reverse Engineering, 111 YALE L.J. 1575 (2002) (analyzing reverse engineering as an important "policy lever" in intellectual property law). 
for Edison to grow wheat since he must compete with someone who had assumed none of the same costs or risks. Society, however, does not protect wheat farmers by giving them exclusive rights to sell all the world's wheat. Rather, society expects them to compete with other wheat farmers in the marketplace by selling the wheat that they have legitimately grown or acquired on their own. Obviously, it is easier to create a competitive market for the identical products of wheat farmers than for the identical products of technology developers. Wheat, unlike technological knowledge, does not have a zero marginal cost of duplication - but that is a practical issue I will address in Part IV. Assuming that it is possible to protect Edison from freeriders but not from independent competitors, this approach would theoretically obviate the appropriation problem as it is commonly understood. Edison would face no more disincentives to develop the light bulb than a wheat farmer faces to grow wheat in a competitive market or a gas station operator faces to set up shop at a well-fueled intersection. ${ }^{52}$ His decision to undertake any invention project should be the result of an analysis that weighs the project's prospective benefits and risks, just as it would be for any other type of economic activity.

By preserving rival inventors' ability to compete based on legitimate investments in research and development, a nonexclusive regime would prevent the preinvention market distortions described in Part II. Inventors would not accelerate their efforts at great cost in order to secure the prize of a temporary monopoly on their invention. They would calibrate their pace of development in order to maximize their returns-as business people do when no patent is at stake. This calculation implicitly balances the value society places upon faster development (i.e., increased revenue by getting to market sooner rather than later) against the opportunity costs (i.e., increased expenses) attributable to accelerating development. If consumers value an invention so much that they are willing to pay higher pricesenough to offset expedited development-then the inventor should speed up his efforts in order to get to market sooner. If there is an acute risk that an invention is not especially valuable to society, the inventor might slow development, reduce costs, and allocate resources to other projects in his research portfolio in order to achieve an optimal risk-reward balance. A nonexclusive patent system allows the development pace to be optimized by a rational economic actor (facing competition from other rational economic actors) whose decisions reflect a finely tuned balance between the value and costs of every specific invention project, without the racing incentives presented by the prospect of gaining or losing a monopoly on a technological improvement.

52. Kenneth Dam makes a similar point. Kenneth W. Dam, The Economic Underpinnings of Patent Law, 23 J. LEGAL STUD. 247, 263 (1994). 
Similarly, the nonexclusive regime would reduce the possibility of anticompetitive behavior in the commercialization of technologies. In cases where the monopoly threat is high (because of low availability of substitutes), inventors would face potential competition from new entrants who independently develop the same technology. The incentive for new entrants to develop technologies would be proportional to the profit potential. New entrants would enter the market until the profits were eaten away by competition. Thus, supernormal rents would not be sustainable over time.

As a property regime, a nonexclusive patent system offers a number of advantages over the tailored liability proposals described above. First, it is a generic framework that can automatically adjust to many different economic contexts. Nonexclusivity not only addresses the substantive aspects of the "patent problem," but also avoids the second-order problem of knowing when the system goes awry. It would not require policymakers to identify situations preemptively where patent-induced market distortions are likely to arise. In place of complex situation-specific rules, nonexclusive patents would induce market participants to behave in the most efficient way possible given industry conditions. Second, nonexclusive patents allow the market to price the value of inventions dynamically based on supply and demand conditions. By contrast, the liability regimes require preset licensing fee schedules that need to be constantly updated and adjusted through an error-prone political process. Finally, a single, generic system of nonexclusive patents would probably require less administration than would a set of liability regimes tailored to different industrial circumstances.

So far, the discussion has centered on how nonexclusive patents would address appropriability issues. As I described in Part I, the other important perceived function of the patent system is its channeling function. It is therefore fair to ask whether nonexclusivity would diminish the patent system's ability to channel investment in research and development. The question is an important one, which raises both practical and theoretical issues. From a practical standpoint, one wonders how the publication requirement-which serves as the institutional basis for the channeling function in the current system-could be compatible with the nonexclusive regime I have defined. This issue derives from Arrow's indivisibility principle. Once someone publishes a technological specification, how can anyone ever claim not to have copied the design from the publisher? Again, I defer this question until the next Part, when I address the broader question of institutional design. For now, I assume that this problem can be avoided as a means of suggesting that nonexclusivity could, in theory, lead to a socially optimal amount of redundant investment in research and development. 
Although it is often assumed that the optimal amount of redundant investment is no redundant investment, this assumption does not hold in a nonexclusive system. The channeling argument focuses on the cost of innovation rather than its value to society. If Edison, in filing his light-bulb patent, publishes a detailed specification of his invention, other inventors might indeed save the cost of coming up with the design on their own. If other inventors are prohibited from commercializing this same invention, prevention of redundant investment is the economically prudent strategy from society's perspective. It is not necessarily the right strategy in a nonexclusive regime, however, because a competitive licensing market may cause licensing fees to drop below noncompetitive licensing fees despite redundancies in research and development. For example, if Edison refuses to license his light-bulb patent at a reasonable rate and there are few substitute designs, those seeking to compete in the market for light bulbs might have to pay more in licensing fees than it would cost them to develop the incandescent lamp themselves. (If Edison refuses to license on any terms, the price is effectively infinite.) The licensees would necessarily pass this cost along to consumers in the form of higher light-bulb prices. Another analogy to the world of physical production illustrates the point. Two or more firms may invest in plant capacity to produce some product-for example, refined gasoline. Although rivalrous production of gasoline might result in redundant plant capacity, capitalist societies do not ordinarily discourage the construction of new plants. The reason is that the cost savings to be gained from combining operations may be offset by higher prices or other inefficiencies from restraint of trade. In fact, such combinations typically generate antitrust scrutiny precisely because of these potential negative effects. ${ }^{53}$

Additionally, in a competitive patent regime there is a greater incentive for inventors to license their inventions-thus avoiding duplicative research and development-than in the current exclusive system. In the current system, owners of patents on important (i.e., nonsubstitutable) technologies have only a carrot incentive to license their technology; that is, the promise of additional revenue through increased marketing and distribution of products containing their technology. The carrot alone, however, may fail to provide sufficient incentive for a potential licensor to coordinate efficient exploilaiion of a paient. ${ }^{54}$ The main reason is that the potential licensor may stand to gain supernormal rents by refusing to license to competitors. Even in cases where the patentee stands to gain more by licensing than by

53. Note that when redundancies grow large and there are significant cost savings available, there is a free-market solution, namely mergers and acquisitions, as long as the combined entity does not run afoul of the antitrust laws.

54. This discussion parallels Merges and Nelson's critique of Kitch's "prospect theory." See Merges \& Nelson, supra note 31, at 871-78. 
excluding, however, many factors such as lack of knowledge, resources, and even cognitive defects may result in a suboptimal quantity of licenses. ${ }^{55}$ Nonexclusivity provides increased incentives to license. Competition from other potential licensors should prompt patent holders to intensify their licensing efforts. The presence of multiple licensors typically increases the likelihood that the technology will be efficiently disseminated, since multiple firms are better able to uncover and exploit new markets for a new technology than is any one firm on its own. ${ }^{56}$

A built-in market mechanism thus causes a nonexclusive patent system to channel research and development away from redundant projects and to do so at reasonable royalty rates without compulsory licensing. In a nonexclusive patent regime, licensing transactions should clear the market at a price below the expected cost of the potential licensee's independent invention effort. For example, suppose Edison, who holds a patent on the light bulb, detects that Swan is in the process of developing a light bulb on his own. Suppose it will cost Swan $\$ 1000$ to complete his development and that Edison reckons Swan has a fifty percent chance of success. It is in Edison's interest to license the invention to Swan at a price below $\$ 2000$, which is Swan's expected cost of independently developing the technology. If Edison charges more than $\$ 2000$, Swan will reject his offer and go it alone. By charging less than $\$ 2000$, Edison is able to absorb the remaining value of Swan's inventive effort. A redundant development expenditure is thereby avoided. It is always in Edison's interest to license to Swan because he will face a new competitor whether Swan licenses the technology or develops it on his own. The only salient question is whether Edison can internalize some of the value of Swan's project through licensing. The presence of competition in a nonexclusive patent system therefore provides great incentive for patent holders to license their inventions. Moreover, since the possibility of rival development places a natural cap on licensing prices that is lower than the cost of independent development, competitors also have a great interest in striking licensing deals with the initial inventor. So while a nonexclusive patent system raises the possibility of redundant invention, market forces should ensure, in the absence of market failure, that inventors generally avoid truly redundant projects.

\section{Designing a NoneXClusive Patent System}

Can it work? In this Part, I explore changes in U.S. patent law that would make a nonexclusive system possible. As I have already mentioned,

55. A burgeoning literature addresses the cognitive limits of rational economic behavior. For a useful overview, see Christine Jolls et al, A Behavioral Approach to Law and Economics, 50 STAN. L. REV. 1471 (1998).

56. Merges \& Nelson, supra note 31, at 873-75. 
nonexclusive patents are conceptually located somewhere inside the existing patent, trade secret, and copyright triangle. I use the patent system as my starting point since a patent-based approach is the "minimal change" option..$^{57}$ I draw comparisons with trade secrecy and copyright at various points, however, when the comparisons help illuminate the nonexclusive patent system.

\section{A. The Independent Invention Defense}

Perhaps the most straightforward approach to opening the patent system to rivalrous independent invention efforts would be to allow defendants in patent litigation to invoke an "independent invention" defense. The patent statute already establishes defenses based on invalidity, noninfringement, and so forth, ${ }^{58}$ but it has historically viewed independent invention as completely irrelevant to the determination of patent infringement. ${ }^{59}$ In 1999 , however, Congress introduced an "earlier invention" defense into the patent law. ${ }^{60} \mathrm{~A}$ defendant may raise this defense if, among other conditions, the alleged infringement involves a method patent that issued more than one year after the defendant had enjoyed (unpatented) commercial use of the technology in question. ${ }^{61}$ Although it has not come without considerable controversy, ${ }^{62}$ the addition by Congress of a defense based on independent invention - even one that applies in highly specified circumstancesrepresents a significant step away from the formerly inviolable principle of patent exclusivity. The move to a more widely applicable independent

57. The addition of reverse engineering protection to trade secret law might, as I have already suggested, be another approach. This strategy, however, would probably require drastic changes (e.g., publication requirements) that would undermine the doctrinal foundations of trade secrecy. Moreover, such a system would probably be unconstitutional if enacted at the state level (the traditional province of trade secret law). See Bonito Boats, Inc. v. Thunder Craft Boats, Inc., 489 U.S. 141 (1989) (holding that state intellectual property law must yield to the extent that it clashes with the balance, struck by Congress in patent laws, between the desire freely to exploit the full potential of inventive resources and the need to create incentives to deploy those resources).

58. See 35 U.S.C. $\$ 282$ (1994 \& Supp. V 1999).

59. See, e.g., Eastman Oil Well Survey Co. v. Sperry-Sun Well Surveying Co., 131 F.2d 884, 887 (5th Cir. 1942).

60. First Inventor Defense Act of 1999, Pub. L. No. 106-113, tit. IV.C, 113 Stat. 1501 A-555 (codified at 35 U.S.C. $\$ 273$ (Supp. V 1999)). The provision was an effort to protect users of secret business methods from patents filed in the wake of State Street Bank \& Trust Co. v. Signature Financial Group, Inc., 149 F.3d 1368 (Fed. Cir. 1998), which held that business methods constitute patentable subject matter.

61. 35 U.S.C. $\$ 273$. At first glance, it may seem puzzling why a defendant's prior commercial use of a technology would not provide an outright invalidity defense. The simple answer is that the prior use may not constitute a "public use," which would invalidate the patent under $\$ 102(\mathrm{~b})$, or may involve "concealment," which would preclude an invalidity claim under $\S 102(\mathrm{~g})$. The case law on noninvalidating prior use is complex and, at times, ambiguous. See Leslie M. Hill, Note, Prior User Defense: The Road to Hell Is Paved with Good and Bad Intentions, 10 FED. CIR. B.J. 513, 518-27 (2001).

62. See, e.g., James R. Bamey, The Prior User Defense: A Reprieve for Trade Secret Owners or a Disaster for the Patent Law?, 82 J. PAT. \& TRADEMARK OFF. SOC'Y 261 (2000). 
invention defense, while certainly bold, would not be completely without precedent.

A generalized independent invention defense would excuse defendants in patent infringement lawsuits when a court determined that the defendant independently developed the invention in question (or licensed from a good-faith independent inventor). Unlike the earlier invention defense, the independent invention defense would apply irrespective of the subject matter of the invention or even the time of development. The only salient fact would be whether the defendant's use of the technology at issue derived from a legitimate invention effort. If Swan, the defendant, legitimately developed the light bulb without copying from the plaintiff, Edison, or if he licensed it from a legitimate third-party inventor, he would not be held liable for infringement.

This simple form of nonexclusivity has its limitations. It creates an asymmetry between the rights of later inventors (i.e., the Swans of the world) to use or license an invention and their rights to prevent others from copying their handiwork. While an independent invention defense allows nonexclusive use of a patented invention, nothing changes the fact that only the first inventor is eligible to receive a patent. In other words, only the first inventor can sue for patent infringement. This fact may be mostly irrelevant as far as the economic case for nonexclusive patents is concerned. ${ }^{63}$ Secondary inventors cannot initiate patent litigation, but they can rely on the patent holder to protect their interests by obtaining injunctions against underhanded copiers. ${ }^{64}$ While subsequent inventors can piggyback on the patent holder for injunctive relief, they do not have any claim to damages the patent holder may receive in compensation for infringement. ${ }^{65}$ Yet this purely distributive fact should not mitigate the deterrent effect of damages on infringing conduct because, from the infringer's perspective, it is irrelevant who gets to keep the award. One might even make a case that the ability to receive damages compensates the first inventor for assuming the disproportionate risk of developing a technology before anyone else has shown it to be possible. ${ }^{66}$

63. Maurer and Scotchmer argue:

It does not matter whether all the firms in the race receive patents, or whether the first inventor receives the patent, and the other independent inventors only receive a defense against infringement. In both cases, enough firms will race so that there is no temptation to duplicate after the patent issues.

Maurer \& Scotchmer, supra note 10 (manuscript at 10 n.5).

64. See 35 U.S.C. $\$ 283$ (1994).

65. See id. $\$ 284$.

66. The mere knowledge that an invention has been successfully developed may significantly reduce invention risk for subsequent inventors relative to the first inventor (assuming subsequent inventors are actually aware of the first inventor's project). The ability of later inventors to rely on earlier inventors' handiwork as a litmus test of the viability of a project could potentially impede high-risk invention efforts (e.g., pioneer inventions) in a nonexclusive regime. The exclusive right to receive damages might provide some cushion against moral hazard (though there is no direct 
In general, as long as the interests of the patent holder and the subsequent inventors are aligned with regard to preventing unauthorized use of the protected invention, the asymmetry between rights to use and rights to sue should not adversely affect subsequent inventors' incentives to invent. Additionally, the mere threat of competitive invention should induce the patent holder to license the invention at a reasonable market-determined rate (below the secondary inventor's expected cost of independent development). A properly functioning licensing market would obviate concerns about secondary inventors' rights to sue infringers since only one party, the original patent holder, would actually "own" the technology in question. Licensors' rights to the technology would derive contractually from the patent holder. Indeed, the licensing rate might even incorporate a slight discount reflecting the subsequent inventors' inability to sue nonpaying infringers.

One can imagine situations in which the interests of patent holders and secondary inventors would diverge. If these situations turn out to be common, a more radical reform to the patent system may be required. I avoid muddying the waters at this point in the discussion and suggest a more radical approach in Section IV.D.

\section{B. Evidence and the Burden of Proof}

Evidence is key to a nonexclusive patent system. Without the blunt instrument of exclusivity to protect inventors from misappropriation, a more precise mechanism is needed to allow inventors to prove conclusively what is and what is not a product of an inventive effort. Indeed, in the nonexclusive realm of trade secrecy, cases often turn on hotly contested interpretations of circumstantial evidence about the defendant's status with regard to the plaintiff's secret. ${ }^{67}$ Once again, our light-bulb example may shed some light on the matter. Suppose Edison announces his discovery of an incredible new type of filament by introducing a working model into the market. Westinghouse knows a good thing when he sees it, so he reverseengineers Edison's light bulb and starts selling it under his own brand. Edison sues, but Westinghouse raises the new defense of independent invention. How can Edison prove that Westinghouse's light bulb is just a knockoff? Proving nonoriginality is very difficult in the domain of functional designs and methods, where the products of invention may have generic features and lack distinctive stamps of authorship. In the absence of

mathematical relationship between the risk level and the damage awards). Maurer and Scotchmer analyze the problem in more depth. See Maurer \& Scotchmer, supra note 10 (manuscript at 14$15)$.

67. See, e.g., Sokol Crystal Prods. v. DSC Communications Corp., 15 F.3d 1427, 1431-32 (7th Cir. 1994). 
a record detailing Westinghouse's inventive activities, Edison is bound to have a hard time making his case. In fact, Westinghouse has every incentive not to keep any records, relegating the dispute to a matter of one inventor's word against another's. ${ }^{68}$

The solution presents itself if we turn the question on its head. In place of the dastardly Westinghouse, consider the scenario of Swan, who independently comes up with Edison's design two months after Edison does. Instead of asking the infringement question from Edison's point of view, let's ask it from Swan's. How can Swan prove that he has not simply copied Edison's design? As it turns out, Swan may be in a very good position to defend himself against charges of misappropriation. He may have kept laboratory notes, written communications, financial records, and other information that would convince an impartial arbiter that he did indeed invent the light bulb on his own. In fact, Swan is the "cheapest cost supplier" of such evidence. ${ }^{69}$ Because he has the most information about his invention efforts as they compare to those of prior entrants in the market, it is more effective to place the burden of proof on Swan to prove noninfringement than on Edison to prove infringement.

Placing the burden of proof on the defendant in an infringement action must be the bedrock of any nonexclusive patent system. Fortunately, the existing patent system is predisposed to placing the burden on the defense once a prima facie case has been established. Once a patent has been issued by the Patent Office, it enjoys an initial presumption of validity in litigation, because the Patent Office has already screened the patent for the essential attributes of novelty, nonobviousness, and so forth. Although courts frequently invalidate patents, the burden of proof lies with the defendant in infringement actions to show that the invention in question is not patentable. $^{70}$ (By contrast, plaintiffs in trade secret lawsuits bear the burden of establishing their rights to the secrets in question, precisely because they are not passed on officially as are patents. $)^{71}$ The independent invention defense does not question the underlying validity of the patent as much as it provides an excuse for a legitimate secondary use. Nonetheless, the statutory imposition of a similar burden of proof on the novel independent invention defense would be a natural extension of existing patent doctrine.

68. Note the court's parenthetical remark in the Sokol trade secret dispute that "any direct evidence ... . would . . . be firmly in the defendant's control." Id. at 1432 .

69. This idea tracks the concept of the cheapest cost avoider in modern tort theory. See Guido Calabresi, Some Thoughts on Risk Distribution and the Law of Torts, 70 YALE L.J. 499, 505-07 (1961).

70. 35 U.S.C. $\$ 282$ (1994 \& Supp. V 1999) ("The burden of establishing invalidity of a patent or any claim thereof shall rest on the party asserting such invalidity."); see also id. $\$ 273(\mathrm{~b})(4)$ (Supp. V 1999) (establishing a similar burden for prior inventor defenses); Paul J. Hayes, Presumptions and Burdens of Proof: Forgotten Tools in Patent Litigation, 26 IDEA 7 (1985) (explaining the importance of burdens of proof in patent litigation).

71. See Cataphote Corp. v. Hudson, 444 F.2d 1313, 1316-17 (5th Cir. 1971). 


\section{Market-Making and Partial Disclosure}

The current patent system's emphasis on complete technical disclosure is tightly bound up with the basic premise of exclusivity. According to the standard economic case, full disclosure channels investment away from technologies whose exclusive rights have already been claimed by previous inventors and into new projects. Indeed, at the opposite end of the exclusivity spectrum, nondisclosure is a fundamental precondition for trade secret protection. ${ }^{72}$

Arrow's indivisibility paradox suggests that full disclosure would raise problems in a nonexclusive regime. One of the goals of the nonexclusive regime is to stimulate an invention market in which secondary inventors license from primary inventors at advantageous prices rather than pursue the socially costly alternative of independent development. For this market to exist, some channeling must occur. Without basic knowledge about what inventions have already been patented and who owns the patents, secondary inventors would pursue redundant projects out of ignorance or inability to establish a licensing negotiation. At the same time, exposure to the technical details of the invention may "pollute" secondary inventors' stock of technical knowledge, precluding the possibility of a successful independent invention defense upon which their negotiating position depends. As long as the publication of the relevant information is conceived as an all-or-nothing choice, Arrow's paradox holds. Exposing Swan to the very information that allows him to approach Edison about a licensing deal removes his ability to raise an independent invention defense, thus giving Edison monopolistic power-the very problem nonexclusivity is meant to solve.

The solution is a system of partial, rather than full (or non-), disclosure that recognizes that all information is not created equal from a marketmaking perspective. Such a system would require significant but manageable changes to the patent publication rules. Under the present system, a published patent consists of a single document containing a wide range of information about the inventor and the invention. In a nonexclusive system, the document would be split into two separate parts: a functional overview and a technical specification. The functional overview would explain in very general terms what an invention dnes without detailing how it works. It would contain basic facts about the inventor and the invention, similar to the opening sections of the patent specification required under the current rules (excluding the detailed description and

72. See Kewanee Oil Co. v. Bicron Corp., 416 U.S. 470, 475-76 (1974). 
drawings)..$^{73}$ It would also contain a substantive overview of the purpose and general function of the invention, similar to the "brief summary of invention" section required under current rules. ${ }^{74}$ The second part of the application would be a technical specification, containing a complete written description, drawings, and claims of novel aspects, as currently required under the patent statute. ${ }^{75}$

The Patent Office would only publish the public functional overview of the invention, although it would keep the technical description on file. Functional disclosure should provide a minimum basis for a licensing market to arise. Prospective inventors could examine the public functional disclosure files before embarking on a project to see if a licensing opportunity exists. If it does, they could contact the patent holder to obtain more detailed technical information or to begin negotiations. While partial disclosure would not provide perfect information to enable a fully transparent licensing market, it would at least form the basis for such a market. Since a competitive patent system would provide great incentives for both parties to come to terms, the functional specification might be all that is needed to spur voluntary information transfers between private parties.

Alternatively, members of the public could "check out" the technical disclosure from the Patent Office. This option would require a waiver of the right to invoke the defense of independent invention. In such a case, the reformed patent system would revert back to its nonexclusive mode of operation for parties that view the technical specifications. Users of the technical information would be effectively barred from developing the invention independently. They could use the technical information, however, to improve the technology and obtain patents of their own. Thus, the check-out option would allow inventors of derivative technologies to stand on the shoulders of their predecessors, just as the patent system

73. See Patent \& TRademark OfFice, U.S. DeP'T of Commerce, Manual of Patent EXAMINING PROCEDURE $\$ 608.01$ (a), II 6.01(a)-(e), at 600-57 (7th ed. 1998).

74. 37 C.F.R. $\$ 1.73$ (2001). The Manual of Patent Examining Procedure provides additional guidance:

Since the purpose of the brief summary of invention is to apprise the public, and more especially those interested in the particular art to which the invention relates, of the nature of the invention, the summary should be directed to the specific invention being claimed, in contradistinction to mere generalities which would be equally applicable to numerous preceding patents. That is, the subject matter of the invention should be described in one or more clear, concise sentences or paragraphs. . . .

The brief summary, if properly written to set out the exact nature, operation, and purpose of the invention, will be of material assistance in aiding ready understanding of the patent in future searches. The brief summary should be more than a mere statement of the objects of the invention ....

PATENT \& TRADEMARK OFFICE, supra note $73, \$ 608.01(\mathrm{~d})$, at $600-60$.

75. 35 U.S.C. $\$ \$ 112-113$ (1994 \& Supp. V 1999); 37 C.F.R. $\$ \$ 1.71,1.74-.75 ;$ PATENT \& TRADEMARK OfFICE, supra note $73, \S 608.01(\mathrm{f})-(\mathrm{g}),(\mathrm{m})$, at $600-61,-63$ to -64 . 
currently permits, if they are willing to relinquish their independent invention rights.

\section{Simultaneous Patents}

My discussion thus far has largely centered around a system that could be established through straightforward (but legally significant) changes to the current patent system. It is conceivable, however, that divergence in interests between patent holders and legitimate secondary inventors could occur. Suppose that Edison International, a multinational conglomerate with a diversified product line, invests in the development of the light bulb and gets a patent. Soon afterward, Swan, an inventor who has staked his company's fortunes on the light bulb, finishes his own substantially similar invention. Swan is a legitimate inventor, so he has the right to commercialize the light bulb. Unfortunately, Edison International decides to pursue other business opportunities and neglects to enforce its light-bulb patent. ${ }^{76}$ Competitors flood the market with knockoff designs and undercut Swan, who needs to charge a higher price if he is to recoup his $R \& D$ investment. Swan implores Edison to enforce the patent but his words fall on deaf corporate ears. Ultimately, Swan shuts down his business.

The risk of nonenforcement by the primary patent holder could reduce secondary inventors' incentives to follow through with a competitive invention project. The next time Swan has a bright idea, he will think twice about carrying it to fruition. Although simple nonexclusivity eliminates the risk of being completely shut out of an invention market after losing an invention race, it still imposes a risk on secondary inventors that the primary patent holder will not protect the invention from cheaters. At the same time, simple nonexclusivity also reduces the winner-take-all upside of the invention race. Indeed, it is no longer a race, since there are multiple winners. The secondary inventor's assessment of the risk of patent nonenforcement, based on his knowledge of competing inventors and industry structure, may cause him to avoid a project he would otherwise pursue were he guaranteed the right to sue cheaters in a nonexclusive regime. While any specific instance of nonenforcement may lead to cheap and plentiful copies of the patented technology, the widespread perception of nonenforcement risk could discourage secondary invention, thus reducing competitive pressure on primary inventors.

76. Patent waste is common among corporate patent owners. A 1998 survey by technology transfer firm BTG International reports that two-thirds of companies fail to exploit their patented technologies and that more than thirty-five percent of patented technologies go unused or unlicensed. Kevin G. Rivette \& David Kline, Discovering New Value in Intellectual Property, HARV. BUS. REV., Jan.-Feb. 2000, at 54, 58-59. 
Full realization of the economic benefits of a nonexclusive regime could therefore necessitate more extensive changes to the patent system. A system of simultaneous patents would give secondary inventors the ability to sue for infringement. One way to implement such a system would be to give the Patent Office the power to merge substantively identical legitimate patents. The parties would become joint owners as defined by the current patent statute. ${ }^{7}$ Each joint owner would have unlimited ability to use or license the invention on a nonexclusive basis. ${ }^{78}$ The joint owners would share the right to initiate patent litigation. ${ }^{79}$ They would also share the legal costs and any damage awards. ${ }^{80}$. A simultaneous patent system would probably increase the number of applications processed by the Patent Office since many inventors who would otherwise not file at all would likely file secondary applications. However, secondary applications could piggyback on primary applications once their overlap was established in order to provide efficiencies in prosecution. Because subsequent inventors would gain patent rights as opposed to a simple defense against noninfringement, determination of independent invention would probably have to be addressed within the Patent Office itself: first by a patent examiner, and then in an administrative hearing if appealed by the secondary applicant or prior patent holder. ${ }^{81}$ Throughout this process, the secondary inventor would bear the crucial burden of proving independent invention.

Ultimately, the cost of operating a simultaneous patent system might outweigh its incremental benefit over a simple regime. If this turned out to be true, there would be two potential policy responses. A radical response might be to dismantle the patent system and replace it with a less bureaucratic regime. The function of the central office could be reduced to keeping records that expedite private litigation (similar to the function of

77. 35 U.S.C. $\$ 262$ (Supp. V 1999).

78. See Talbot v. Quaker-State Oil Ref. Co., 104 F.2d 967, 968 (3d Cir. 1939).

79. Presently, an infringement action may be dismissed if all joint inventors do not join the suit. See Vaupel Textilmaschinen KG v. Meccanica Euro Italia S.P.A., 944 F.2d 870, 875-76 (Fed. Cir. 1991). This rule would wreak havoc on a nonexclusive system and would likely need to be addressed in the statute.

80. As the experience of joint owners under $\$ 262$ has shown, conflicts of interest among rightsholders would, from time to time, complicate joint patent ownership and litigation efforts. Potential problems include lack of control over patent exploitation; uncertainties relating to patent maintenance, enforcement, and future development; and uncertainties created by a joint owner's bankruptcy. However, these problems can be resolved through contractual agreement. See Edward V. Filardi, Ownership of Intellectual Property Assets-Contracting, Joint Development, and alliances, in INTELleCtuAl PROPERTY ISSUES IN STRUCTURING DEALS AND DRAFTING AGREEMENTS 67, 75-78 (PLI Patents, Copyrights, Trademarks \& Literary Prop. Course, Handbook Series No. G0-00TA, 2001). Best practices, such as those identified by Filardi, could be added to $\S 262$ as a default rule in order to encourage rival inventors to work together to protect their common interests.

81. This could be a variant of the inter partes reexamination procedure introduced in 1999. See Optional Inter Partes Reexamination Procedure Act of 1999, Pub. L. No. 106-113, tit. IV.F, 113 Stat. 1501 A-567 (codified at 35 U.S.C. $\$ \$ 311-318$ ). 
the Copyright Office), or the office could be eliminated entirely (moving closer to a trade secret system). Radically restructuring the Patent Office would obviously require an incredible amount of institutional change, however. If the costs of administering simultaneous patents were to outweigh the economic benefits, the sensible alternative would be simply to fall back on an independent invention defense as a second-best solution.

\section{BEYOND LIGHT BULBS}

Thus far, I have referred to a single idealized example-the incandescent lamp-in order to explain how nonexclusive patents would affect the market for innovation. To speak of a single, undifferentiated innovation market is, of course, a simplification. Inventors may compete throughout many different stages of technological development, from the upstream realm of basic scientific discoveries to the more applied arena of incremental or cumulative invention, and ultimately to the market for finished products. ${ }^{82}$ In this Part, at the risk of oversimplifying some extraordinarily complex policy debates, I briefly evaluate nonexclusive patents in the context of two current patent controversies. My goal is not to resolve conclusively either of these issues, but simply to give a sense of the applicability and potential benefits of nonexclusive patents throughout the invention life cycle and across a range of cutting-edge industrial scenarios.

\section{A. Upstream Discovery: The Case of Biopatents}

The past quarter-century has seen major advances in scientific understanding of the basic building blocks of human life and the ability to use this knowledge to create new drugs and medical treatments. Many important discoveries have been patented by private companies and by universities that increasingly view technology transfer as a new source of research funding. Since Diamond v. Chakrabarty, ${ }^{83}$ in which the Supreme Court upheld a patent on a genetically engineered strain of bacteria, the courts have repeatedly upheld patents on living matter deemed to be a product of "human invention," ${ }^{84}$ including genes ${ }^{85}$ and scientifically engineered cells that otherwise exist in nature. ${ }^{86}$ These patents apply at the

82. See Barton, supra note 37 , at 451 .

83. 447 U.S. 303 (1980).

84. Donna M. Gitter, International Conflicts over Patenting Human DNA Sequences in the United States and the European Union: An Argument for Compulsory Licensing and a Fair-Use Exemption, 76 N.Y.U. L. REV. 1623, 1636-43 (2001).

85. Amgen, Inc. v. Chubai Pharm. Co., 927 F.2d 1200, 1203 (Fed. Cir. 1991).

86. Moore v. Regents of the Univ. of Cal., 793 P.2d 479, 492-93 (Cal. 1990). 
level of basic science. The protected technologies are typically many steps removed from any marketable product or treatment.

Proponents of biopatents emphasize that these patents provide essential incentives to invest in biotechnology research, much of which is funded by the private sector. Biotechnology research can represent an extreme case of Arrow's appropriability problem because of the vast gulf between the large investment required to identify, say, a valuable gene, and the ease with which this knowledge can be used at no cost by someone else who knows exactly where to look. Without patents, researchers would be unable to appropriate the value of their discoveries. Moreover, some evidence suggests that control over upstream rights can improve the effectiveness of downstream research. ${ }^{87}$

Critics argue that patents on basic scientific discoveries can hold up downstream innovation, leading to deadweight loss. Parceling out tracts on the genetic landscape, for example, caps the potentially enormous social value of the most critical genes. Basic patents may have claims broad enough to restrict not only marketing of products based on follow-on research, but also the research itself ${ }^{88}$ Even narrow patents may prove overly restrictive if there is no possibility of inventing around the claims. ${ }^{89}$ Researchers and drug developers may have to negotiate licenses for patented discoveries that undergird entire fields of medicine. ${ }^{90}$ High transaction costs and limited institutional resources can prevent patentees from licensing to all potential downstream users of the patent, thus limiting the number of research paths that may ultimately be pursued..$^{91}$ Moreover, patent holders may not want to license to certain downstream researchers, because of strategic aims or methodological biases. ${ }^{92}$ In other words, patents on fundamental biological discoveries may make follow-on research more expensive and more homogeneous, and may ultimately impede the development of useful and cost-effective medical treatments based on the latest scientific advances. In order to mitigate this social loss, critics propose a variety of liability rules and ex post remedies, including

87. Arti K. Rai, Fostering Cumulative Innovation in the Biopharmaceutical Industry: The Role of Patents and Antitrust, 16 BERKELEY TECH. L.J. 813, 828-30 (2001).

88. Barton, supra note 37 , at 454.

89. Rai, supra note 87 , at 842 .

90. One topical example of such a potentially far-reaching patent is the Wisconsin Alumni Research Foundation's patent on the primate stem cell, U.S. Patent No. 6,200,806 (issued Mar. 13, 2001). See Sheryl Gay Stolberg, Parent on Stem Cell Puts U.S. Officials in a Bind, N.Y. TIMES, Aug. 17, 2001, at A1 (describing the patent's broad scope).

91. Rai, supra note 87 , at 831-36.

92. Rebecca S. Eisenberg, Patents and the Progress of Science: Exclusive Rights and Experimental Use, 56 U. CHI. L. REV. 1017, 1057-60 (1989). 
compulsory licensing of upstream patents and increased antitrust scrutiny where basic patents are involved. ${ }^{93}$

Compared to these proposals, nonexclusive patents could provide a better means of balancing the needs of upstream science and downstream R\&D for all the reasons I suggested in Part III. In place of compulsory licensing using a predetermined one-size-fits-all royalty formula, the threat of competitive entry in a nonexclusive regime would encourage patentees to license their discovery voluntarily to all comers at a reasonable, marketdetermined rate. If the primary patentee holds up exploration of other potentially fruitful derivative research paths because of institutional limitations (or for strategic reasons), rivals would have an incentive to recreate the basic innovation and fulfill the unmet licensing need. Rivals will enter as long as they can profit by licensing the discovery to as yet unsatisfied downstream users. However, faced with the prospect of a new competitor willing to satisfy unmet demand, the rational response on the part of the resource-constrained primary patent holder would be to extend its "distribution" reach by entering into agreements with technology transfer firms that have the capability to license the innovation to the widest possible market of users. The primary patent holder's desire to capture some of the surplus value that would otherwise go to rival inventors should stimulate the development of a viable secondary licensing market, ensuring that the upstream discovery finds its way to the socially optimal number of downstream users willing to pay reasonable royalties for its use.

One of the greatest challenges in constructing biotechnology patent policy follows from the difficulty of predicting, a priori, the social value of any given biopatent. One patented gene may hold the key to an array of essential cancer-fighting medicines. Another may prove to have no medical utility whatsoever. One process for developing human stem cells may remain the best available method over the life of a twenty-year term. Another may become obsolete as soon as the ink is dry on the patent application. In many cases, a patent may lie in the middle of this value spectrum, maintaining its value for a few years before some new discovery eclipses it.

Nonexclusive patents provide a dynamic pricing mechanism that allows scientists and investors to receive a fair return on their initial investment, without overcompensating them at society's expense if the discovery turns out to have fundamental medical importance over the long term. The

93. See Barton, supra note 37, at 458-66 (suggesting an antitrust approach); Eisenberg, supra note 92 , at 1078 (arguing for a limited experimental-use exception in the case of scientific claim validation and compulsory licensing for follow-on research); Gitter, supra note 84, at 1678-90 (proposing a compulsory license regime with a broader exemption for experimental use); Rai, supra note 87, at 838-53 (arguing for narrower PTO guidelines and stepped-up antitrust enforcement, and against compulsory licensing). 
reason, as I noted in Part II, is that $R \& D$ costs for any given project may decline over time as the underlying technology of invention advances. As the expected cost of independent invention decreases, the pressure on primary patentees facing the threat of competitive entry to lower prices increases. As a consequence, in a nonexclusive system, the longer an upstream patent retains its value for downstream users, the greater the pressure on the patentee to license at lower prices. At the limit, where some discovery (e.g., stem cells) turns out to form the basis for a whole new scientific field and the upstream patent holder continues to charge exorbitant prices, downstream industry participants may decide to back a rival research program qualified to raise the independent invention defense on the condition that it make the technology available for public use at little or no cost.

\section{B. Cumulative Systems Development: The Case of Software Patents}

Although computer software, like biotechnology, is an innovationdriven industry, software innovation tends to be more cumulative and informal. While some portion of computer programming involves abstract development of discrete concepts by formally trained professionals (and can be properly termed "computer science"), a large proportion involves practical artistry that occupies a downstream realm far removed from the basic enabling inventions. Programmers commonly combine and recombine software design elements that have worked in other contexts. ${ }^{94}$ Compared to inventors in other technical fields, they more often rely on informal modes of information dissemination rather than on professional journals, patent disclosures, and the like. Unattributed ideas often flow freely within the programming community. Programmers tend to pick up technical knowhow from many different sources as they work their way through various technical problems. ${ }^{95}$ Unconstrained by physical manufacturing processes, software technologies can evolve at a very rapid pace.

Traditionally, computer software has been protected against competitive appropriation through copyright or trade secrecy. However, as the software industry has matured, its products have grown more complex, and the financial stakes have increased, limitations of these regimes have become more apparent. Trade secrecy does nothing to stop the appropriation of technical knowledge through reverse engineering of a program. ${ }^{96}$ While copyright protects against literal copying of code, it does not adequately cover nonliteral appropriation of basic software

94. Samuelson et al., supra note 8 , at 2330-31.

95. Id. at 2329-30.

96. See supra note 51. 
functionality. ${ }^{97}$ Consequently, developers have turned to the patent system for additional protection of their valuable investment in software technology.

Courts have increasingly accommodated their wishes..$^{98}$ In the 1970 s, courts repeatedly viewed software as mathematical algorithms, which, under Gottschalk v. Benson, ${ }^{99}$ could not be patented. Starting with Diamond v. Diehr in $1981,{ }^{100}$ however, courts began to uphold software patents as long as they described inventions as processes instantiated in physical machines rather than as purely logical methods. By the 1990s courts decreased the formal barriers to software patents in a string of cases culminating in the Federal Circuit's State Street decision, which held that algorithmic processes are patentable as long as they produce a "useful, concrete, and tangible result." ${ }^{101}$ A surge in software patents has paralleled this history. As many as 100,000 software patents may now be in force in the United States, with thousands more issuing every year. ${ }^{102}$

Despite the increasing prevalence of software patents, the peculiar characteristics of the software industry raise at least two important problems, both involving transaction costs. First, it can be costlysometimes impossible - to pinpoint the original source of any given software improvement. The dispersion of downstream technical knowledge, combined with the "black box" nature of compiled code, can make prior art searches difficult. These search costs can lead to uncertainty, excess litigation, and, in the worst case, enforceable patents on inventions of questionable (but not disprovable) novelty. Second, the fast pace of software advances may limit the potential economic benefit of information channeling through the formal apparatus of the patent system. Development often outpaces the patent system's ability to publish technical information. By the time a patent applicant has drafted a formal application and submitted it to the Patent Office, and the publication window passes, several other developers may have made the same technological advance. Even for the rare programmer who religiously searches the patent database before starting a coding session, the publication of a relevant patent may come too late to do any good. Enforcement of exclusive rights may shut down independent invention even when independent invention is more cost- and time-efficient than relying on a prior inventor's patent disclosure.

97. Samuelson et al., supra note 8, at 2343-56.

98. See Julie E. Cohen \& Mark A. Lemley, Patent Scope and Innovation in the Software Industry, 89 CAL. L. REV. 1, 7-11 (2001) (describing the history of software patents).

99. 409 U.S. 63 (1972).

100. 450 U.S. $175(1981)$. 1998).

101. State St. Bank \& Trust Co. y. Signature Fin. Group, Inc., 149 F.3d 1368, 1373 (Fed. Cir.

102. Cohen \& Lemley, supra note 98 , at 11. 
By providing strong protection against misappropriation while preserving independent developers' ability to maneuver and defend themselves against overly restrictive software patents, nonexclusive patents would provide an elegant solution to the software dilemma. In contrast to some proposed tailored liability approaches, ${ }^{103}$ nonexclusive patents would not require special rules or pricing schedules unique to the software industry. Rather, the same nonexclusive system that would apply to other industries would also apply to the software business. Developers could apply for patents to protect innovations, as they do now. The risks of error in prosecution, however, would be minimized because independent invention (or derivation from an independent invention) would provide a defense to infringement actions based upon spurious patents. Nonexclusive patents would allow independent invention to continue to flourish as long as industry participants determine that it is cheaper (or faster) to build than to search for a patented technology. By protecting incentives to innovate while preserving free competition among legitimate competitors, nonexclusive patents should lead to lower prices, increased innovation, and more open technology access than the current patent system. ${ }^{104}$

In presenting the tough cases of biotechnology and software, my goal has been to show the versatility of nonexclusive patents. Part of the appeal of a nonexclusive patent system is that it would be flexible enough to adapt to both these outlier situations as well as more conventional invention scenarios.

\section{CONCLUSION}

To answer the question posed at the outset of this Note, I believe that society would be better off by giving both Edison and Swan rights to commercialize the light bulb. A nonexclusive patent system would be more economically efficient than an exclusive patent system. In theory, nonexclusive patents should generally improve social welfare across a range of invention scenarios where competition leads to price competition among rival patent holders or increased licensing at reasonable market rates. A nonexclusive system could be constructed through modifications to the existing patent regime. It could have far-reaching effects in many stages of technological development and across many industries.

At this point, of course, the idea is merely a hypothesis. Following further theoretical development, the next step would be to test this hypothesis with willing participants in an appropriate microcosmic

103. E.g., Samuelson et al., supra note 8, at 2413-20.

104. These benefits should be particularly pronounced in situations where a patented technology produces network extemalities that give the patent holder disproportionate market power. 
industrial setting. Ideally, the industry context would be one where patents currently lead to monopoly power due to lack of substitutes. A subfield of biotechnology might be a good candidate. In conducting such an experiment, we would want to know first whether the system I have described-or some other "preferred embodiment" of a nonexclusive patent regime-is technically feasible. If it is feasible, we would want to conduct a positive analysis of its economic impact in comparison to the current exclusive patent regime. Although I have primarily approached this issue from the patent angle, we might also want to know how nonexclusive patents would fare in an industrial context that currently favors trade secrecy. (For example, would a partial disclosure system lead to more efficient channeling of information that is presently kept secret?)

For present purposes, however, I will be satisfied if, in the spirit of Edison and Swan, I have been able to offer a novel source of illumination in an occasionally dusky area of the law. 
***

Imaged with the Permission of Yale Law Journal 